\title{
Ethnobotanical Documentation of Wild Edible Plants Used by Gujjar Community of Tarai West Forest Division Ramnagar, Nainital, India
}

\author{
KAILASH CHANDRA PANDEY*1 and NEETA PANDE ${ }^{2}$ \\ 'Department of Botany, P. N. G. Govt. P. G. College, Ramnagar Nainital, Uttarakhand, India. \\ ${ }^{2}$ Department of Botany, M. B.Govt. P. G. College, Haldwani, Nainital, Uttarakhand, India. \\ http://dx.doi.org/10.12944/CWE.11.3.16
}

(Received: October 09, 2016; Accepted: November 21, 2016)

\begin{abstract}
The present investigation highlights the identification and documentation of wild edible plants used by Gujjar community in foothills of Shiwalik range of Kumaun Himalaya. Survey method by using semi structured interview schedule with the Gujjar community was used to collect the information. During the survey, a total of 51 plants belong to 33 families and 46 genera were listed as edible, out of which $39 \%$ trees, $25 \%$ shrubs, $22 \%$ herbs and $14 \%$ were climbers. Various parts of the plant were used as food, of which fruits and leaves were extensively used. The study also deals with the availability status of listed plants, about 13 plants found abundantly, 09 were common and 29 plants placed in rare category. The results emerge from this study suggested that exploration and documentation of wild edibles plants offer new variety of food to be added in the healthy diet but their survival in near future is threatened due to lack of awareness and documentation. Therefore, both wild edibles plants as well as traditional knowledge need priority action for conservation.
\end{abstract}

Keywords: Gujjar, Wild edible, Tarai West Forest Division, Ethnobotany.

\section{INTRODUCTION}

Uttarakhand, a Himalayan state of India, is known for its biodiversity as well as rich heritage of wild edible plants. Uttarakhand has a total area of $53,483 \mathrm{~km}^{2}$ of which $86 \%$ is mountainous and $65 \%$ is covered by forest ${ }^{1}$. Forests play a very important role in the life of tribal as well as communities as they provide significant ecosystem services in the form of food, fodder, fruits, timber and medicine $e^{2,3,4,5,6,7}$ etc.

Wild edible plants are the major source of food for the tribal inhabitants and satisfy considerably the food requirements of the economically poor population in rural areas. Edibles parts of these plants (seed, fruits, flowers, leaves, delicate stems, roots and rhizomes) are the nature's gift to human beings. The wild plants are not only delicious and refreshing but also the chief source of vitamins, proteins and minerals ${ }^{8}$. They are easily available within forest habitat and most of the tribal and rural communities depend on these wild resources to meet their daily food requirements in the period of food scarcity as well as for food supplement ${ }^{[9]}$. Other than this, in comparison of cultivated crop the taste of wild plants is natural and also free from toxic substances like pesticide and other hazardous chemicals generally used in cultivated crops.

Survey and documentation of wild edible plants and their use have been conducted in several parts of the country by various workers ${ }^{10,11,12,13,14}$ and several others). In Uttarakhand, some attempt has also been done to explore the ethnobotany values of plants and the documentation of wild edibles by various scientist as well as researchers ${ }^{15,16,17,18}$. However, very little work has been done on wild edible plants used by Gujjar community. Gujjars are the forest dwellers frequently collecting woody and non woody wild products from the forest to 
sustain their life. Knowledge of non-domesticated food resources is a part of traditional knowledge and is largely transmitted through socialization and household context. Gujjars are considered as the storehouse of traditional knowledge about uses of plants for various purposes. Mostly the elders of the community have immense knowledge about the use of wild pants as fruits and vegetables but on the other hand, it was noticed that the younger generation showing very little interest in the tradition and culture and thus have a little knowledge about the traditional use of flora and fauna. To keep these things in view, the present study was carried out with the objectives to document the indigenous uses and availability status of wild edible plants used by the Gujjar community and also tries to conserve their traditional knowledge.

\section{MATERIALS AND METHODS}

\section{Study area}

The study area, Tarai West Forest Division Ramnagar (T.W.F.D.R), is situated in the foothills of Shiwalik Mountains of outer Himalaya near Corbett National Park, Ramnagar, Nainital. This division is sub-divided into seven ranges which include Aampokhra range, North Juspur Range, West
Juspur Range, Kashipur Range, Bannakhera Range, Bailparav Range and Ramnagar Range (Fig.1). The study sites were located within the coordinates of $29^{\circ} 12^{\prime} 30^{\prime \prime}$ to $20^{\circ} 23^{\prime} 20^{\prime \prime} \mathrm{N}$ and $78^{\circ} 47^{\prime} 30^{\prime \prime}$ to $79^{\circ}$ $19^{\prime} 40$ "E. Average elevation ranges from 221 to 385 mtrs msl. It covers 34807 hectares and blessed with diverse type of vegetation.

\section{Data Collection}

Regular field trips were made during 2015 to 2016 in order to collect the information about wild edible plants and their indigenous uses. Different ranges of the forest division were surveyed extensively in different seasons (i.e. rainy, winter, summer) with Gujjars to know the value of wild edibles. Due to poor literacy only the semistructured interview were conducted. Photographic documentation was also helpful for long period conservation of knowledge of wild edibles. Members of the different age groups were interviewed. During survey not only plant phenology was studied but also availability status of plants (i.e. abundant, common and rare) also recorded. The plants pointed out by Gujjars were collected, identified botanically with the help of existing literature of T.W.F.D.R. and taxonomic experts of different institutions. To ensure the authenticity and reliability of primary data were

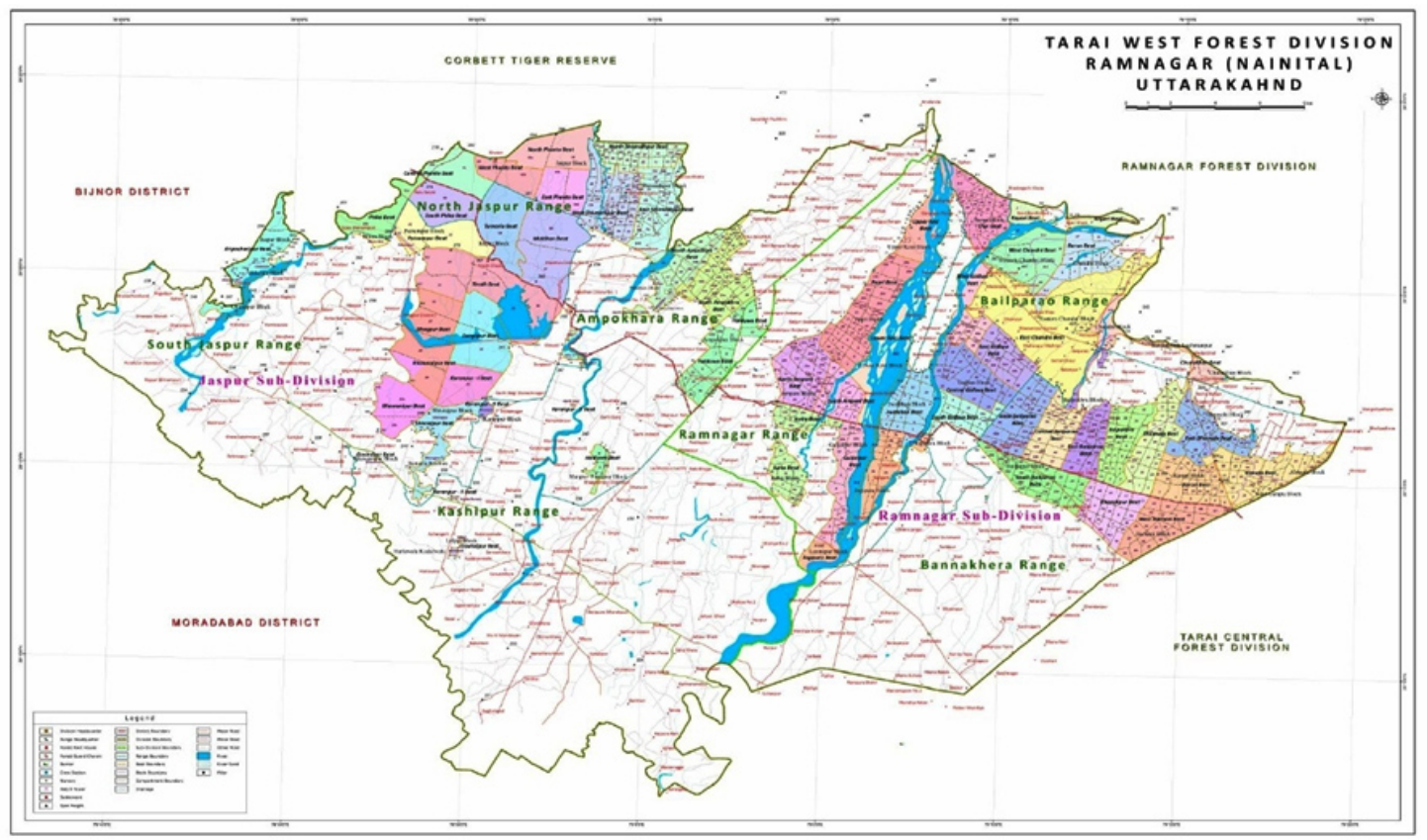

Fig.1: Map of study area 


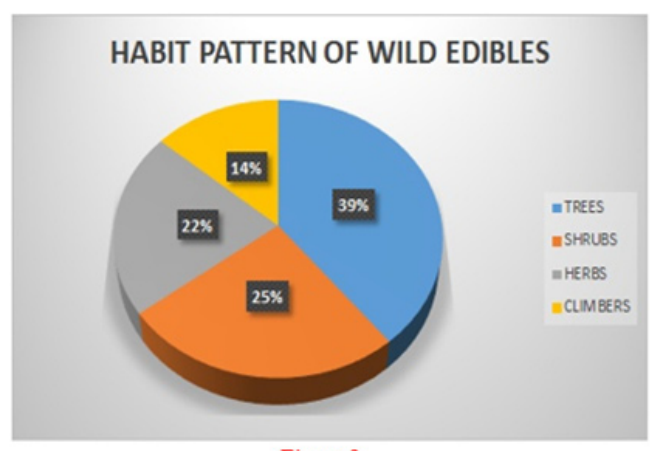

Figure 2.

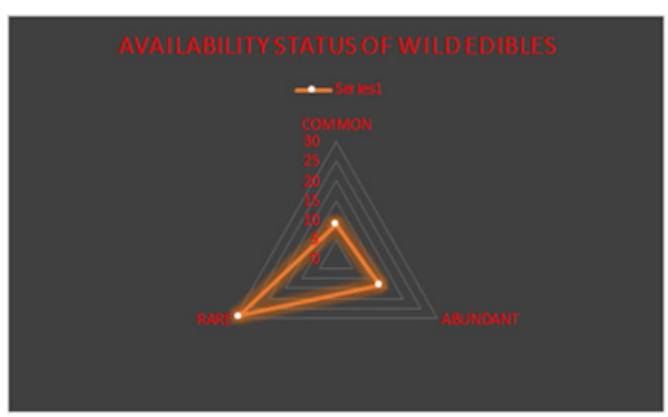

Figure 4.
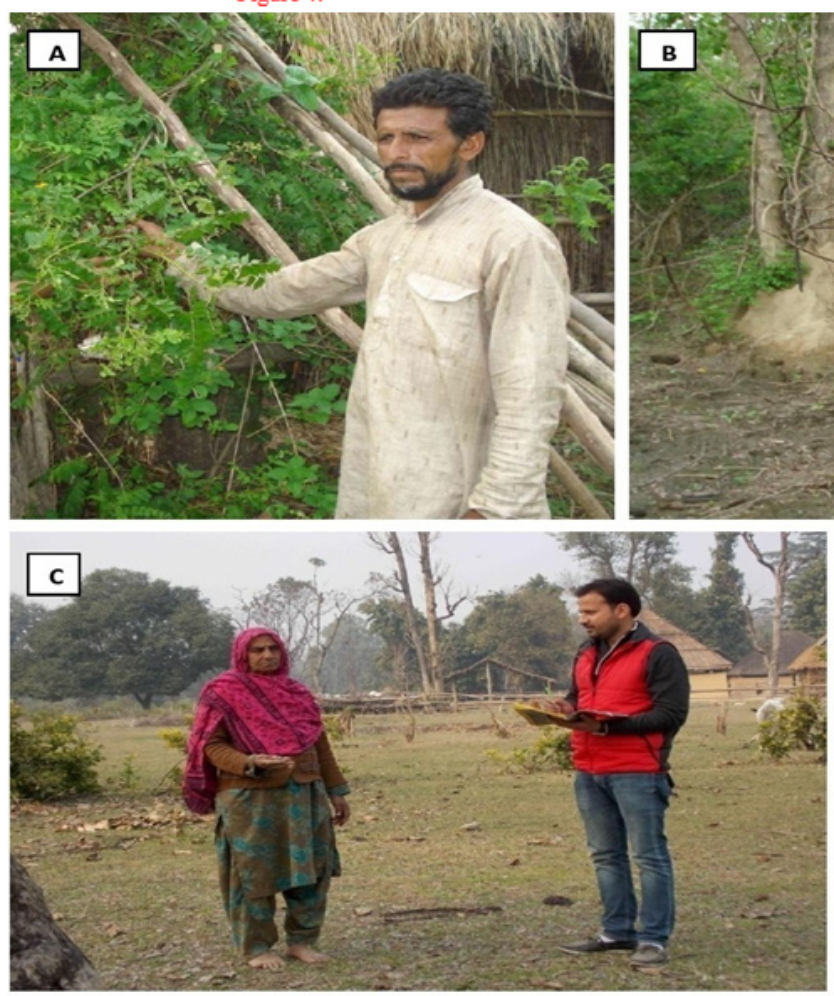

\section{DIFFERENT FORMS OF FOOD ITMES}

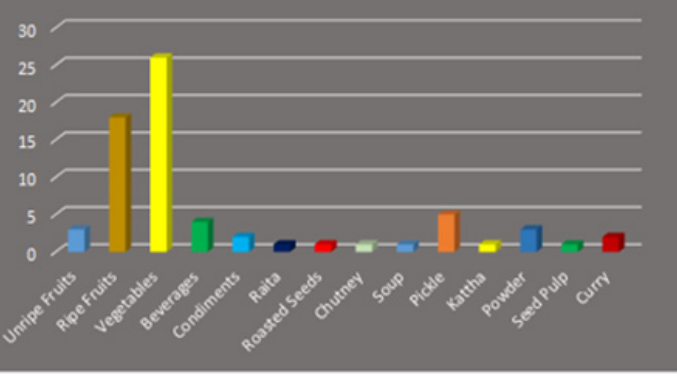

Figure 3.

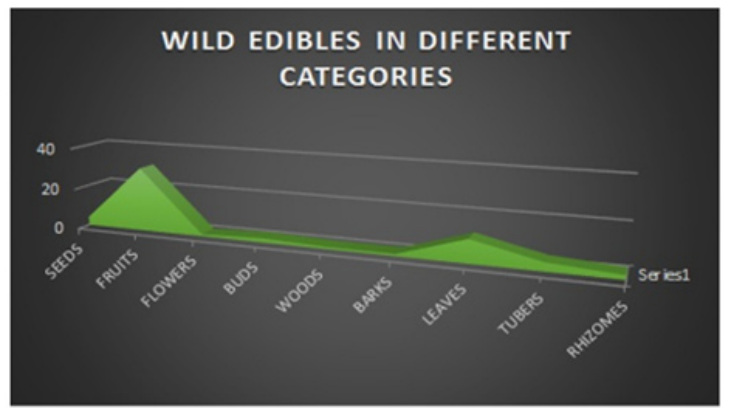

Figure 5 .
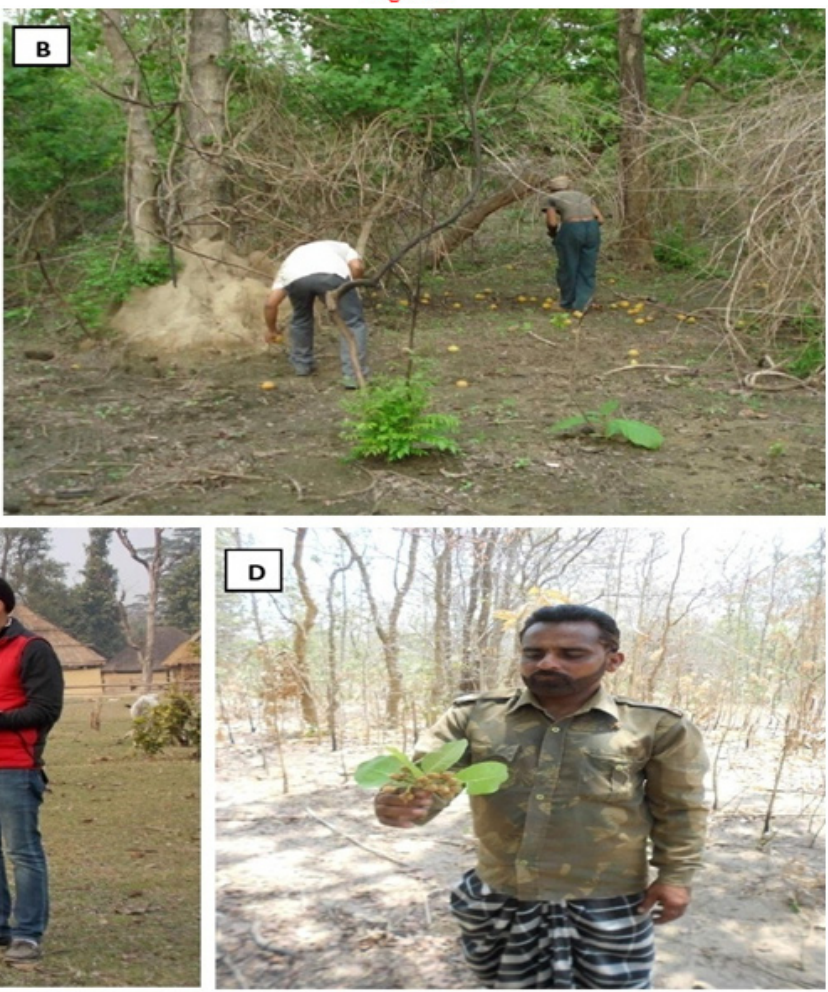

A- Male Gujjar enlightening about the use of Melia azadirachta.

B- Gujjars collecting Aegle marmelos.

C- Gujjar lady telling about Terminalia chibula.

D- Male Gujjar showing fruit of Madhuca indica. 


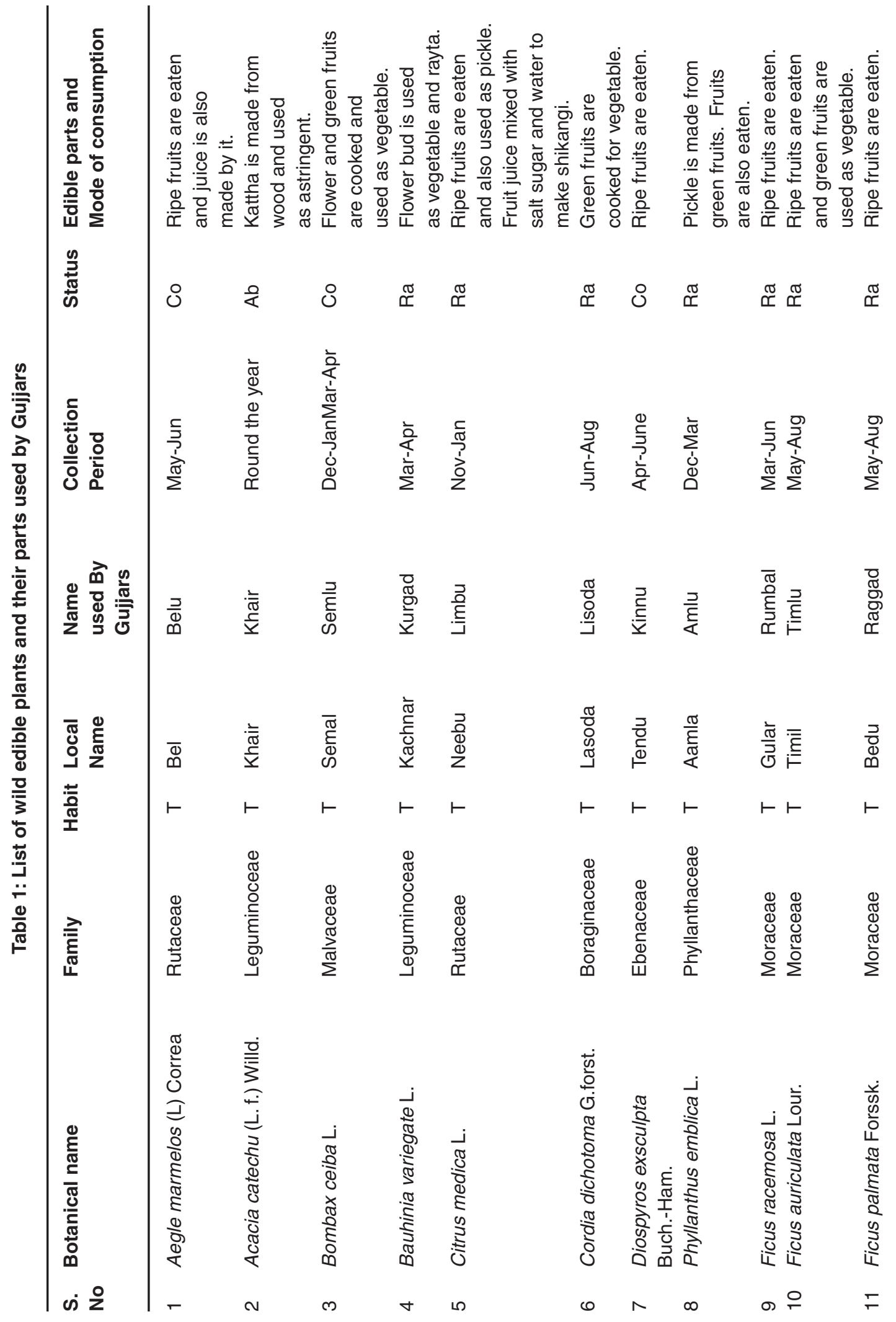




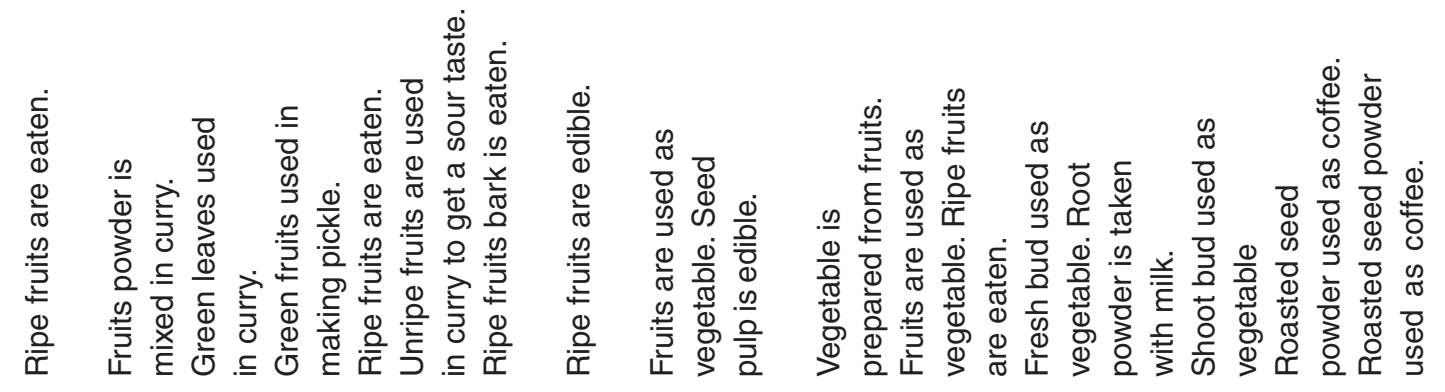

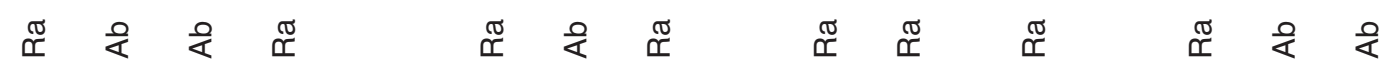

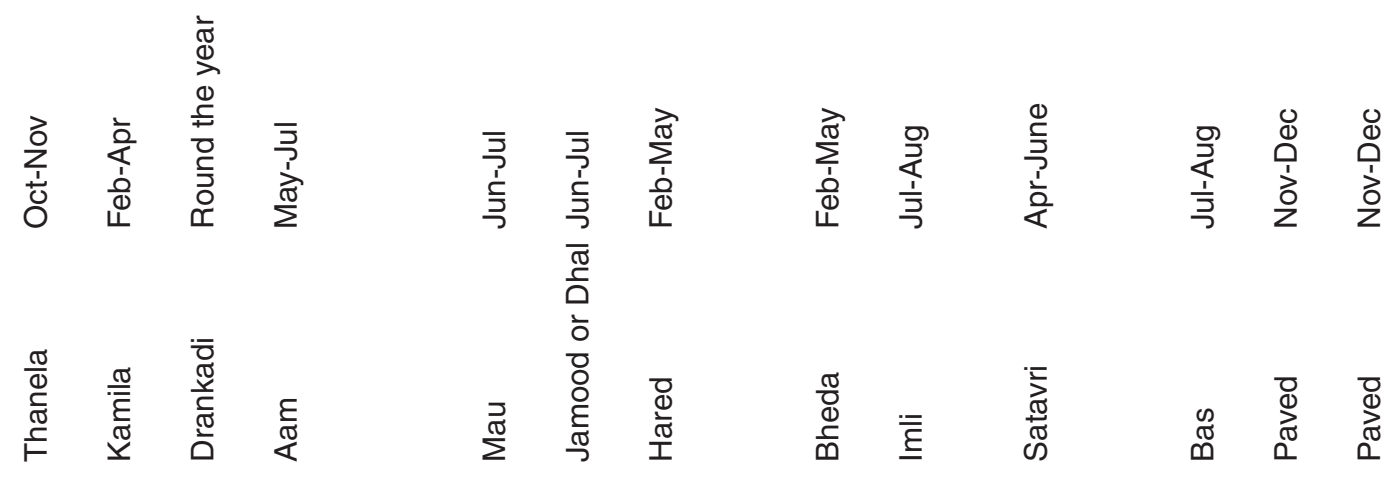

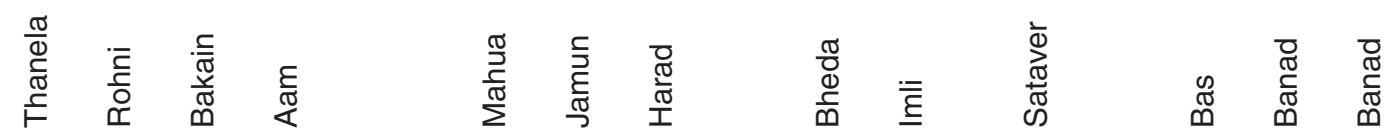

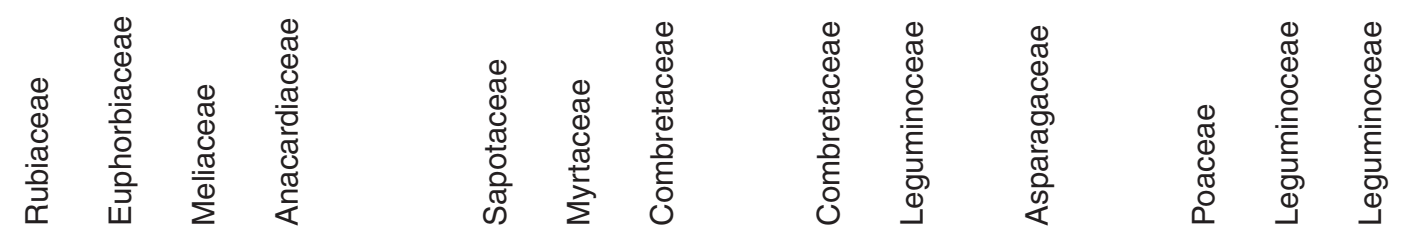
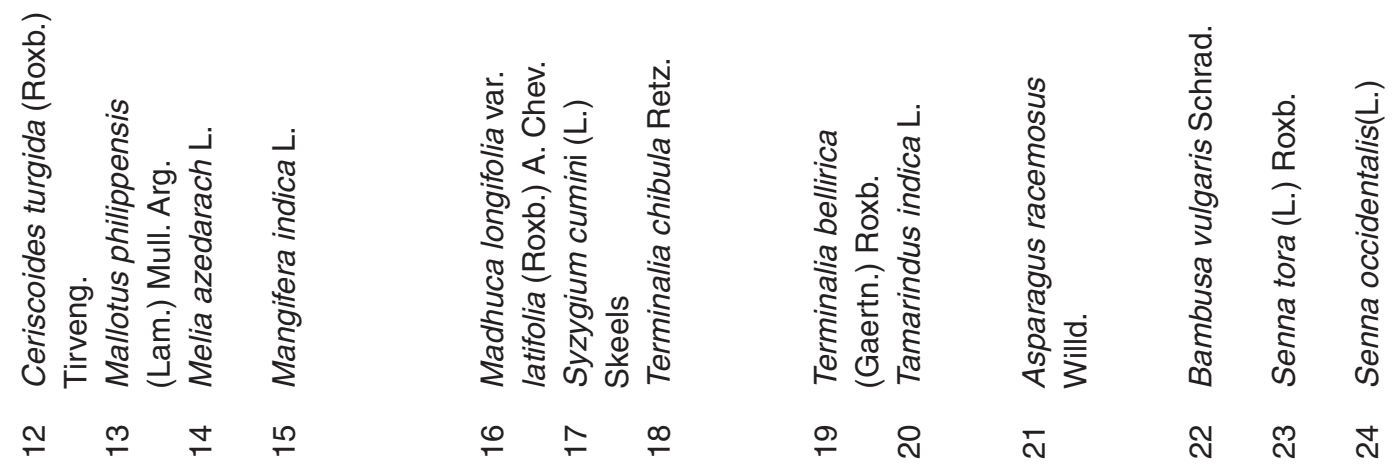


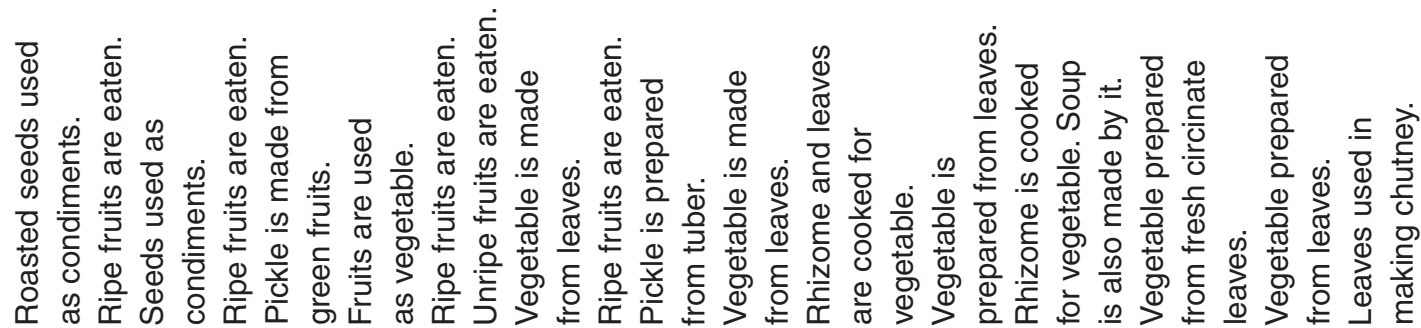

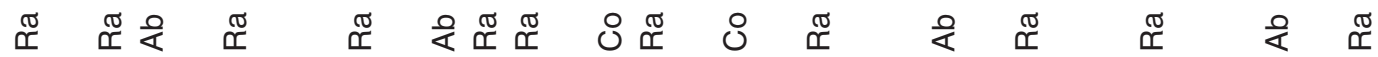

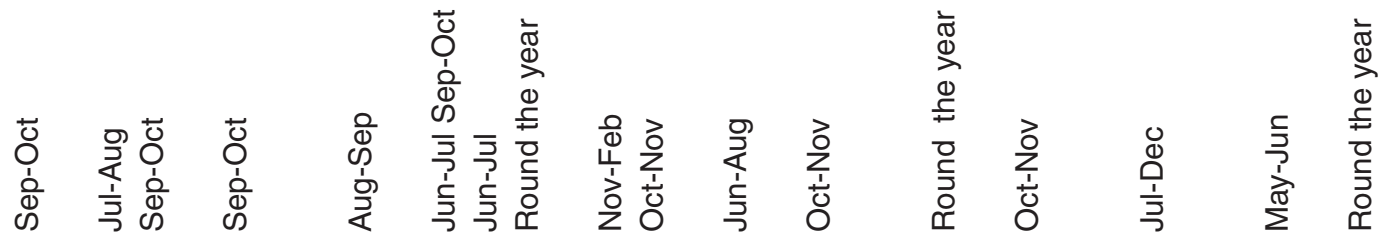

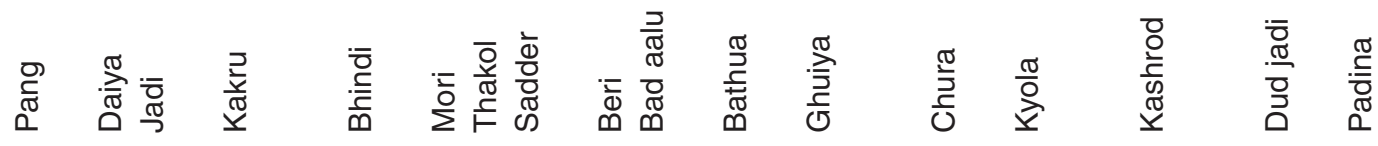

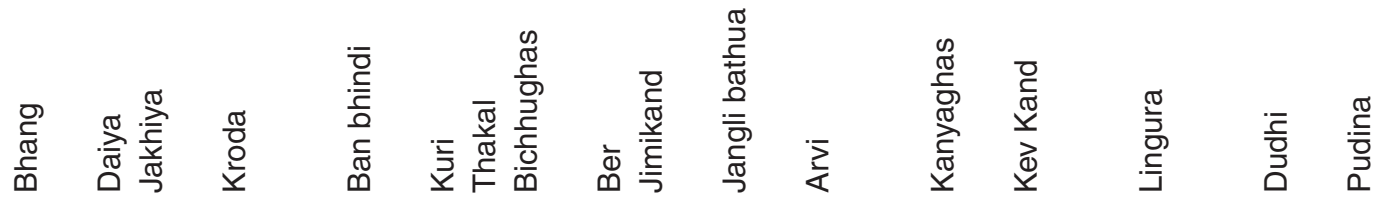

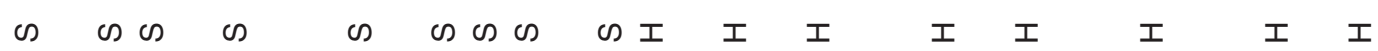

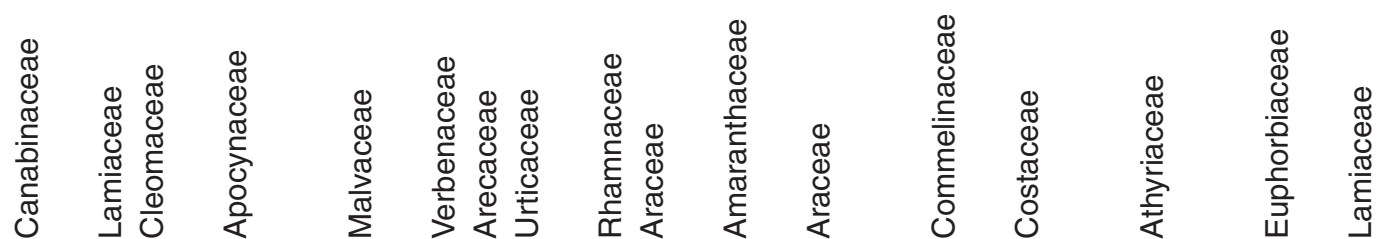

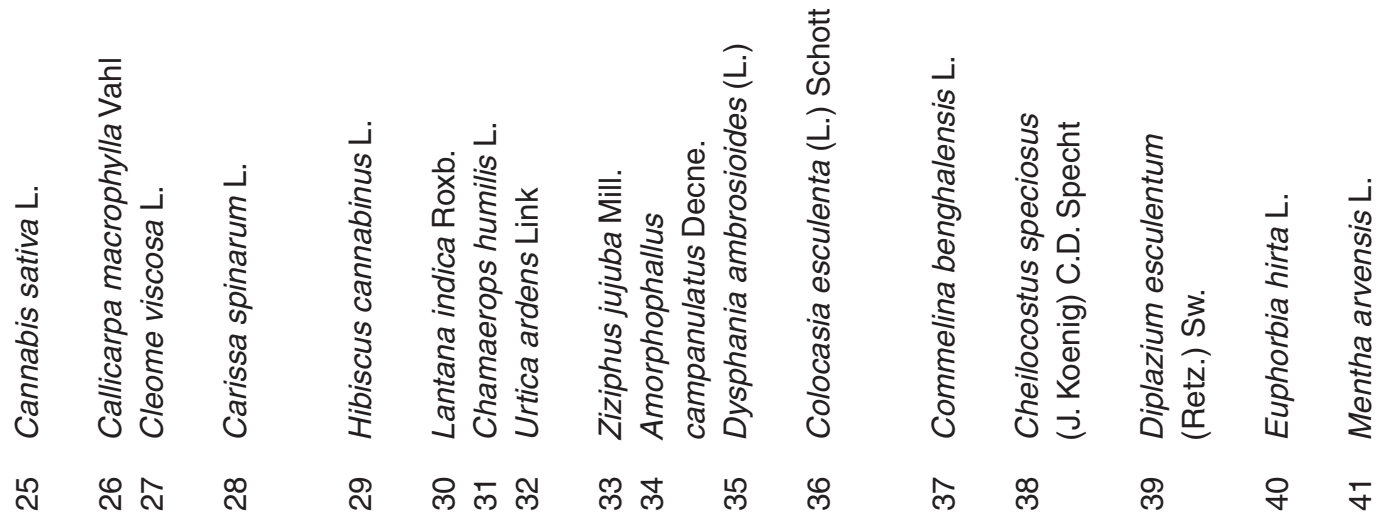




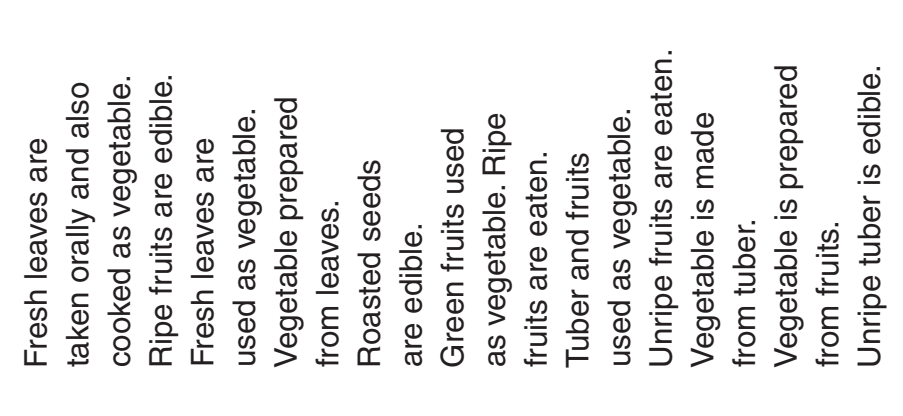

\& $\quad$ \&

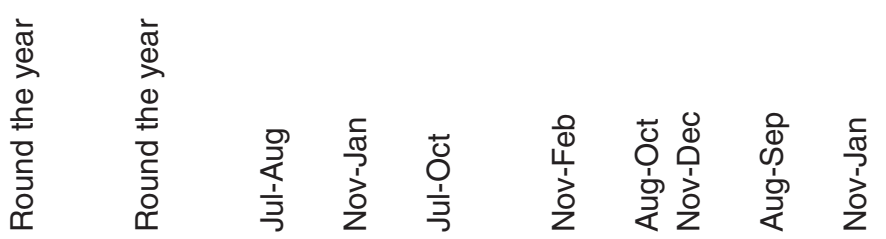

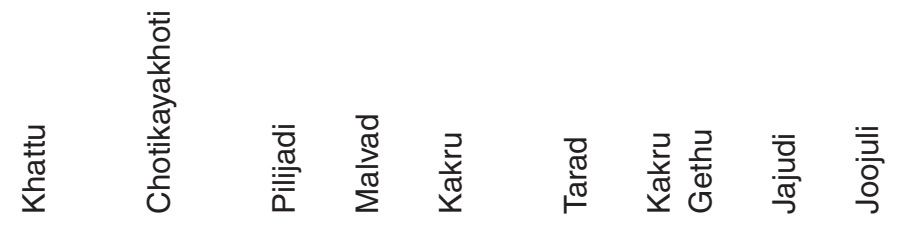

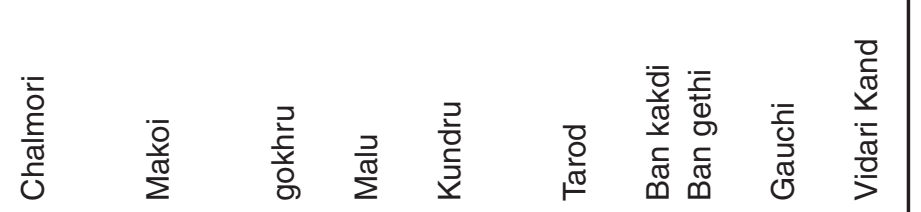

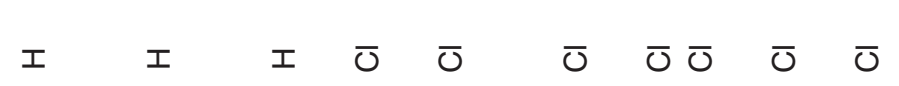

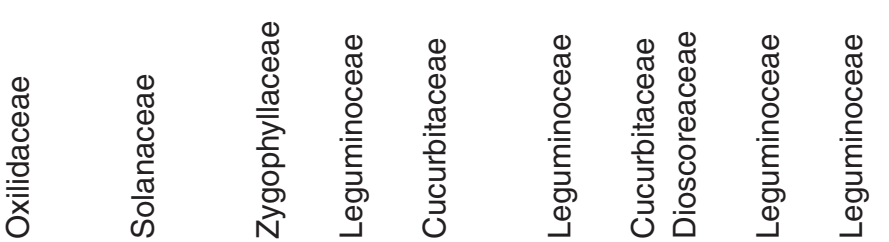

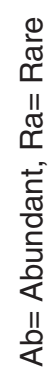

(1)

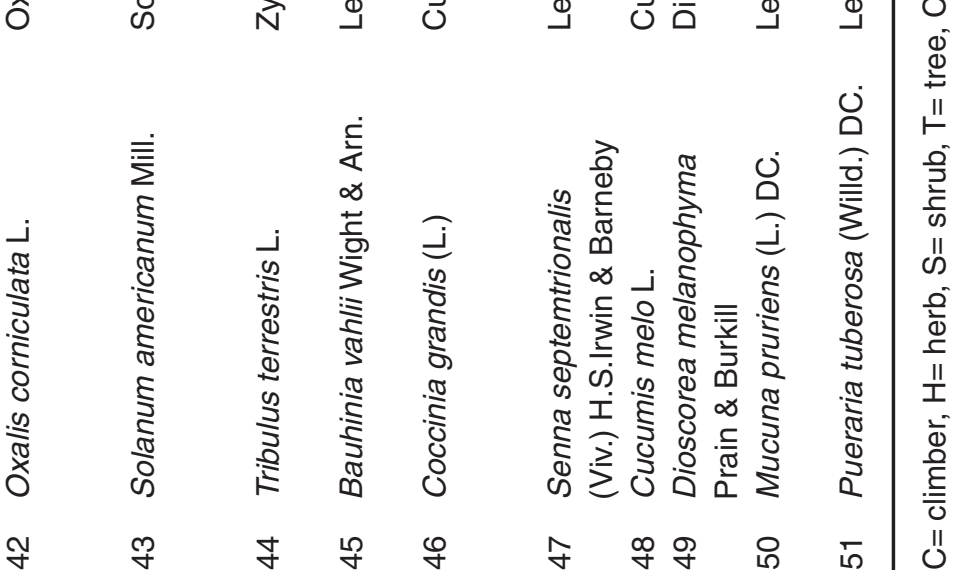




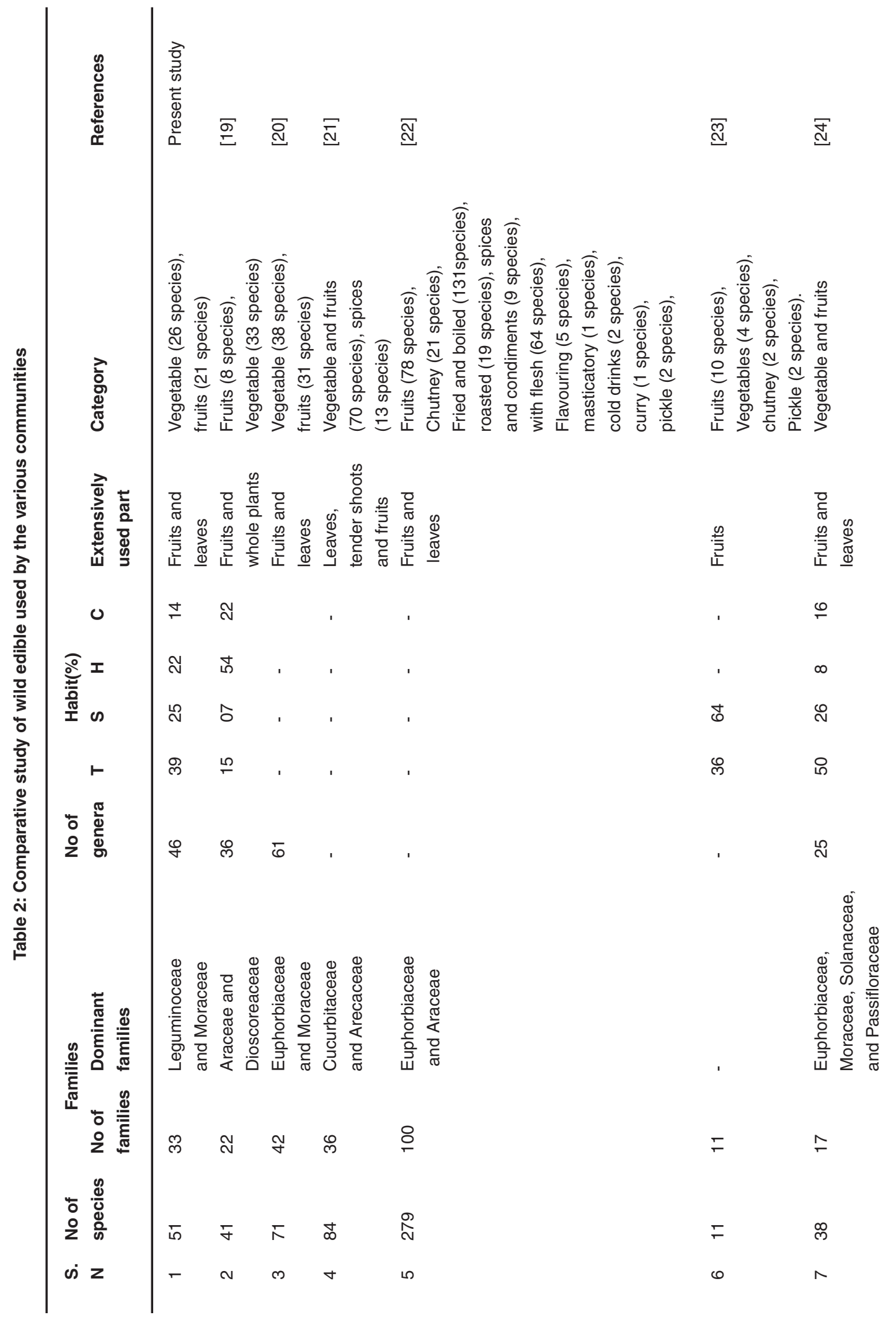


also verified by informants (Gujjar) at different ranges of forest division.

\section{RESULTS}

In the present study, a total of 51 plant species belongs to 46 genera and 33 families were used by Gujjar community (Table 1). Out of the total plants species $39 \%$ trees, $25 \%$ shrubs, $22 \%$ herbs and $14 \%$ were climbers (Fig.2). These plants have been arranged alphabetically and the information collected is divided into botanical name, name used by Gujjar, local name, family, parts used, uses and availability status. Gujjars generally used the fresh plant or plant parts but some time they store them in various forms and use throughout the year at the time of scarcity. Wild edibles diversity was recognised accordingly to their seasons of availability on the way of survey. Leguminoceae and Moraceae are the most dominant families. The different wild edibles are used as in different forms like vegetable (26 plants), condiments (1 plant), roasted seed (1 plant), curries ( 2 plants), beverages ( 2 plants), soup (1 plant), raitya (1 plant), chutney ( 1 plant) pickles (5 plants), ripe fruits (18 plants), unripe fruits (3 plants), seed pulp (1 plant), juice (1 plant), shikanji (1 plant), kathha (1 plant) and powder (3 plants) (Fig.3). It was also found that most of the wild edibles are used as vegetable $(51 \%)$ and in the form of ripe fruits $(35 \%)$. On the basis of the investigation made, wild edibles were categorized in abundant, common and rare categories, registering 13, 09 and 29 plants, respectively (Fig.4). During survey it was also noticed that the wild edibles were used in different categories like seeds, fruits, flowers, buds, woods, barks, leaves, tubers and rhizomes, of which fruits and leaves were eaten mostly (Fig.5).

\section{DISCUSSION}

The results deal with 51 wild edible plants utilised by the Gujjar community. These wild edibles having natural taste and are free from pesticides. The floristic diversity of the study site offers variety in human diet. A comparative account of wild edibles used by the various communities is given (table 2). Present study have less reported plants as compare to other studies i. $e^{20,21,22,25}$ while placed higher as reported by ${ }^{19,23,24,27}$ and more or less similar as reported by ${ }^{26}$. According to the utilization pattern of 
the various parts of the plant, fruits and leaves were the extensively used parts, show similarity as early reported.

Indigenous fruits play an important role in the nourishment of rural and ethnic communities from the very beginning. Mostly the elder Gujjars have vast knowledge about these wild plants as meal or food supplements. Moreover, due to over exploitation, the wild flora is declining very sharply. Other than this, unfortunately, the younger generation is also not taking any interest to maintain this traditional knowledge bank, hence resulting in the degradation of folk flora. Introduction of exotic fruit is also a big cause to decline the knowledge of wild edible in between the community. Therefore, it is recommended that specific attention should be paid to these wild edibles. By this study an attempt was also made to gather knowledge about the conservation status of wild plants. It was suggested by this study, that there are number of plants which are either rare or not abundant hence require significant attention before they become endangered or extinct. For this purpose such studies have always play an important role regarding the cultivation of traditionally used wild plants and also in maintaining the gene pool of rare plants.

\section{ACKNOWLEDGMENTS}

The authors are thankful to the authorities of Government P.G. Colleges of Haldwani and Ramnagar for providing laboratory facilities. The Gujjar community and the staff of Tarai West Forest Division, Ramnagar are also acknowledged for their kind support and cooperation.

\section{REFERENCES}

1. https://en.wikipedia.org/wiki/Uttarakhand.

2. Padalia K, Bargali K, Bargali SS. How does agroforestry systems support ethnobotanical values in Kumaun Himalayan Bhabhar belt? African Journal of Traditional Complementary and alternative Medicines, 12(6): 100-112 (2015)

3. Parihaar RS, Bargali K, Bargali SS. Diversity and uses of Ethno-medicinal plants associated with traditional agroforestry systems in Kumaun Himalaya, Indian Journal of Agricultural Sciences 84(12):1470-1476 (2014)

4. Gosain BG, Negi GCS, Dhyani PP, Bargali SS, Saxena R. Ecosystem Services of Forests: Carbon Stock in Vegetation and Soil Components in a Watershed of Kumaun Himalaya, India. International Journal of Ecology and Environmental Sciences, 41 (3-4): 177-188 (2015)

5. Pande N, Pandey KC. Ethno-veterinary health treatment by Gujjar community of Kalagarh Range in Corbett National Park Uttarakhand, India, International Journal of Tropical Agriculture, 33(4): 3077-3082 (2015)

6. Pandey KC, Pande N. Traditional Medicinal Plants of Gujjar Community in Dhela Range of Corbett National Park (Uttarakhand, India),
The Journal of Ethnobiology and Traditional Medicine. Photon : 1113-1123 (2015)

7. Pande PC, Awasthi P, Bargali K, Bargali SS. Agro-Biodiversity of Kumaun Himalaya, India: A Review, Current Agriculture Research Journal, 4(1):16-34 (2016)

8. Kumar S, Hamal IA. Wild edibles of Kishtwarheigh altitude National Park in northwest Himalaya, Jammu \& Kashmir (India); Ethnobotanical Leaflet, 13: 195-202 (2009)

9. Rashid A. Less known wild edible plants used by the Gujjar Tribe of district Rajouri, Jammu and Kashmir state India, International journal of Botany, 4(2): 219-224 (2008)

10. Borthakur SK. Wild edible plants in markets of Assam, India-An Ethnobotanical investigation, In S.K. Jain. (ed.) Ethnobiology in Human Welfare. Deep Publication, New Delhi, 31-34 (1996)

11. Negi KS, Gaur RD. A contribution to the edible wild fruits of Uttar Pradesh hills. Bulletin of the Botanical Survey of India, 33: 233-266 (1991)

12. Rasingam L. Wild edible Tubers and Rhizomes of the Nilgiri Biosphere Reserve. Newsletter Nilgiri Natural History Society, 1: 3 (2010)

13. Singh HB, Arora RK. Wild edible plants of 
India, ICAR, New Delhi, (1978)

14. Samant SS, Dhar U. Diversity, endemism and economic potential of wild edible plants of Indian Himalaya, International Journal of Sustainable Development and World Ecology, 4: 179-191 (1997)

15. Gaur RD. Wild edible fruits of Garhwal hills. The Himalaya, 1: 66-70 (1977)

16. Pant PC. Flora of Corbett National Park, Uttar Pradesh, Botanical Survey of India, Howrah, (1986)

17. Mehta PS, Kumar D, Bhatt KC. Wild edible plant species for subsistence in Kumaon Himalaya and associated traditional knowledge, Journal of Economic and Taxonomic Botany, 30: 340352 (2006)

18. Kala CP. Prioritization of cultivated and wild edibles by the local people in the Uttaranchal hills of Indian Himalaya, Indian Journal of Traditional Knowledge, 6: 239-243, (2007)

19. Deb D, Sarkar A, Deb B, Barma, B.K. Datta, Majumdar K. Wild edible plants and their utilization in traditional recipes of Tripura, Northeast India. Advances in Biological Research 7(5): 203-211 (2013)

20. Singh B, Sinha BK, Phukan SJ, Borthakur SK, Singh VN. Wild edible plants used by Garo tribes of Nokrek Biosphere Reserve in Meghalaya, India, Indian Journal of Traditional Knowledge, 11(1): 166-171(2012)

21. Gangte HE, Thoudam NS, Zomi GT. Wild edibles plants used by the Zou Tribe in
Manipur, India. International Journal of Scientific and Research Publications, 3(5):1-8 (2013)

22. Kar A, Bora D, Borthakur SK, Goswami NK, Saharia D. Wild edible plant resources used by the Mizos of Mizoram, India, Kathmandu University Journal of Science Engineering and Technology, 9(1): 106-126 (2013)

23. Deshmukh BS, Waghmode A. Role of wild edible fruits as a food resource: Traditional knowledge. International Journal of Pharmacy and Life Sciences. 2(7): 919-924 (2011)

24. AjeshTP, Abdulla SA. Naseef, Kumuthakalavalli R. Ethnobotanical documentation of wild edible fruits used by Muthuvan tribes of Idukki, Kerala, India. International Journal of Pharmaceutical and Bio Sciences 3(3): 479 - 487 (2012)

25. Rasingam L. Ethnobotanical studies on the wild edible plants of Irula tribes of Pillur Valley, Coimbatore district, Tamil Nadu, India, Asian Pacific Journal of Tropical Biomedicine 14931497 (2012)

26. Dangwal RL, Singh T, Singh A. Exploration of wild edible plants used by Gujjar and Bakerwal tribes of District Rajouri (J\&K), India. Journal of Applied and Natural Science 6(1): 164-169 (2014)

27. Sharma P, Agnihotry A, Sharma PP, Sharma L. Wild edibles of Murari Devi and surrounding areas in Mandi district of Himachal Pradesh, India, International journal of Biodiversity and Conservation, 5(9): 592-604 (2013). 